\title{
Anal Mucosal Melanoma with KIT-Activating Mutation and Response to Imatinib Therapy - Case Report and Review of the Literature
}

\author{
Imke Satzger Uta Küttler Bernward Völker Florian Schenck Alexander Kapp \\ Ralf Gutzmer
}

Skin Cancer Center Hannover, Department of Dermatology and Allergy, Hannover Medical School, Hannover, Germany

Key Words

Mucosal melanoma, metastatic - Imatinib • c-KIT protein expression

\begin{abstract}
Previously an increased frequency of KIT aberrations in mucosal melanomas was reported, whereas C-KIT in most types of cutaneous melanomas does not appear to be of pathogenetic importance. Imatinib has become the standard of care in other cancers with KIT mutations such as gastrointestinal stromal tumors. Recently 12 cases of metastatic melanoma and KIT-activating mutations have been published to be successfully treated with c-KIT blockers such as imatinib, sunitinib, dasatinib or sorafenib. We report here on one of our patients with KIT-activating mutation in metastatic anal mucosal melanoma, who showed a response to imatinib therapy and summarize the available literature regarding this new therapeutic option. Copyright $\odot 2009$ S. Karger AG, Basel
\end{abstract}

\section{Case Report}

In December 2007, a 79-year-old female patient complained of anal bleeding. In coloscopy a pigmented nodular lesion was discovered in the posterior wall of the lower rectum. A biopsy of the tumor mass revealed proliferation of atypical epithelioid cells with pleomorphic features. Immunohistochemistry showed strong positivity for HMB45 and Melan A, whereas cytokeratins 1, 7, 5 and 14 and S-100 expression were negative, consistent with the diagnosis of anal mucosal melanoma. In addition, c-KIT staining demonstrated positive results in $>75 \%$ of tumor cells (fig. 1a), DNA sequence analysis revealed a KIT-activating mutation of L576P in exon 11 (fig. 1b). CT scans of the chest and abdomen revealed no evidence of metastasis, and complete removal of the tumor was achieved by wide local excision. In September 2008, the patient suffered from an extensive local recurrence with a visible part of the tumor mass at the posterior rectum (fig. 2a). CT scans of the chest and abdomen demonstrated 12 pulmonary metastases and pathological lymph nodes in the inguinal region on both sides. S-100 protein $(2.56 \mu \mathrm{g} / \mathrm{l}$, upper normal limit 0.2 $\mu \mathrm{g} / \mathrm{l})$ and lactate dehydrogenase (592 U/l, upper normal limit $235 \mathrm{U} / \mathrm{l}$ ) in serum were highly elevated. The recurrence could not be resected completely; a diverting colostomy had to be implanted for palliative therapy. The patient suffered from weakness, weight loss and loss of appetite; the tumor mass at the posterior rectum caused a painful foreign-body sensation. From October 2008, the patient was started on oral imatinib $400 \mathrm{mg}$ daily as palliative therapy. Already 2 weeks later, her performance status was markedly improved. The visible part of the rectal tumor mass decreased (fig. $2 b-d$ ) and the patient was no longer impeded by the foreign-body sensation. S-100 protein and lactate dehydrogenase in serum were falling (fig. 3). Within the first 4 weeks of imatinib therapy at a dose of $400 \mathrm{mg} /$ daily, the patient developed mild limb edemas and nausea. After increasing the dose of imatinib to $800 \mathrm{mg} /$ day intermittently for 1 week, the nausea deteriorated in spite of treatment with ondansetron and metoclopramide. During the following weeks, $400 \mathrm{mg}$ imatinib daily was well tolerated. Restaging 12 weeks after initiation of imatinib revealed a significant improvement of the local recurrence. Lung metastases having measured

\section{KARGER}

Fax +41613061234 E-Mail karger@karger.ch www.karger.com
Imke Satzger, MD

Skin Cancer Center Hannover

Department of Dermatology and Allergy, Hannover Medical School

Ricklinger Strasse 5, DE-30449 Hannover (Germany)

Tel. +495119246 0, Fax +495119246 422, E-Mail satzger.imke@mh-hannover.de 


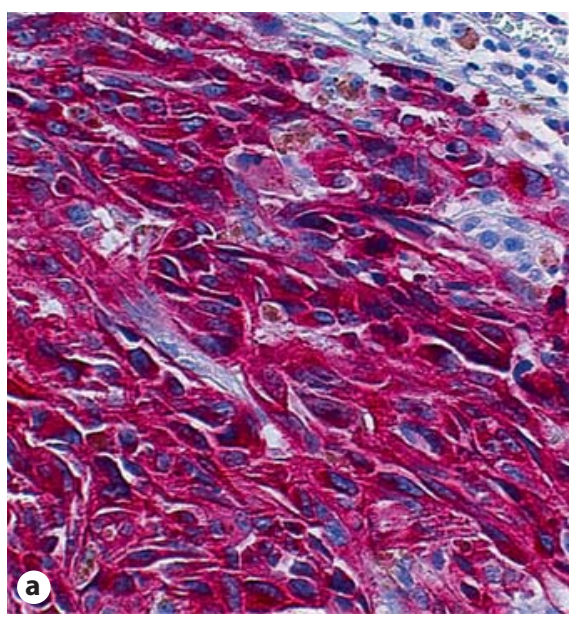

Fig. 1. a Immunohistochemical staining of the primary mucosal melanoma showed strong c-KIT staining in $>75 \%$ of melanoma cells. b KIT genotyping demonstrated an activating mutation (arrow) in exon 11 (L576P). The upper curve depicts the KIT exon 11 forward sequence, the lower curve the wild-type sequence.

up to $1.8 \mathrm{~cm}$ before treatment (fig. 4a) decreased to $1.2 \mathrm{~cm}$ (maximal diameter, fig. 4 b). The inguinal lymph node metastases were slightly enlarged (before treatment 42 and $44 \mathrm{~mm}$, respectively; after treatment 44 and $48 \mathrm{~mm}$, respectively). However, the radiologist considered both inguinal lymph nodes to be possibly enlarged as a reaction to therapy (table 1).

Unfortunately, the patient developed concurrent problems unrelated to melanoma and imatinib therapy. First, she suffered from a loss of vision due to aggravation of a preexisting glaucoma. Second, she became more and more depressive due to her familial situation.

Thus, she decided to discontinue imatinib therapy although it was highly recommended for melanoma treatment. Finally, she died in March 2009 only 10 weeks after the end of imatinib therapy.

\section{Review and Discussion}

Thus far in unselected patients suffering from metastatic melanoma, the use of targeted therapies which target specific mechanisms involved in the oncogenic process have been more or less frustrating [1].

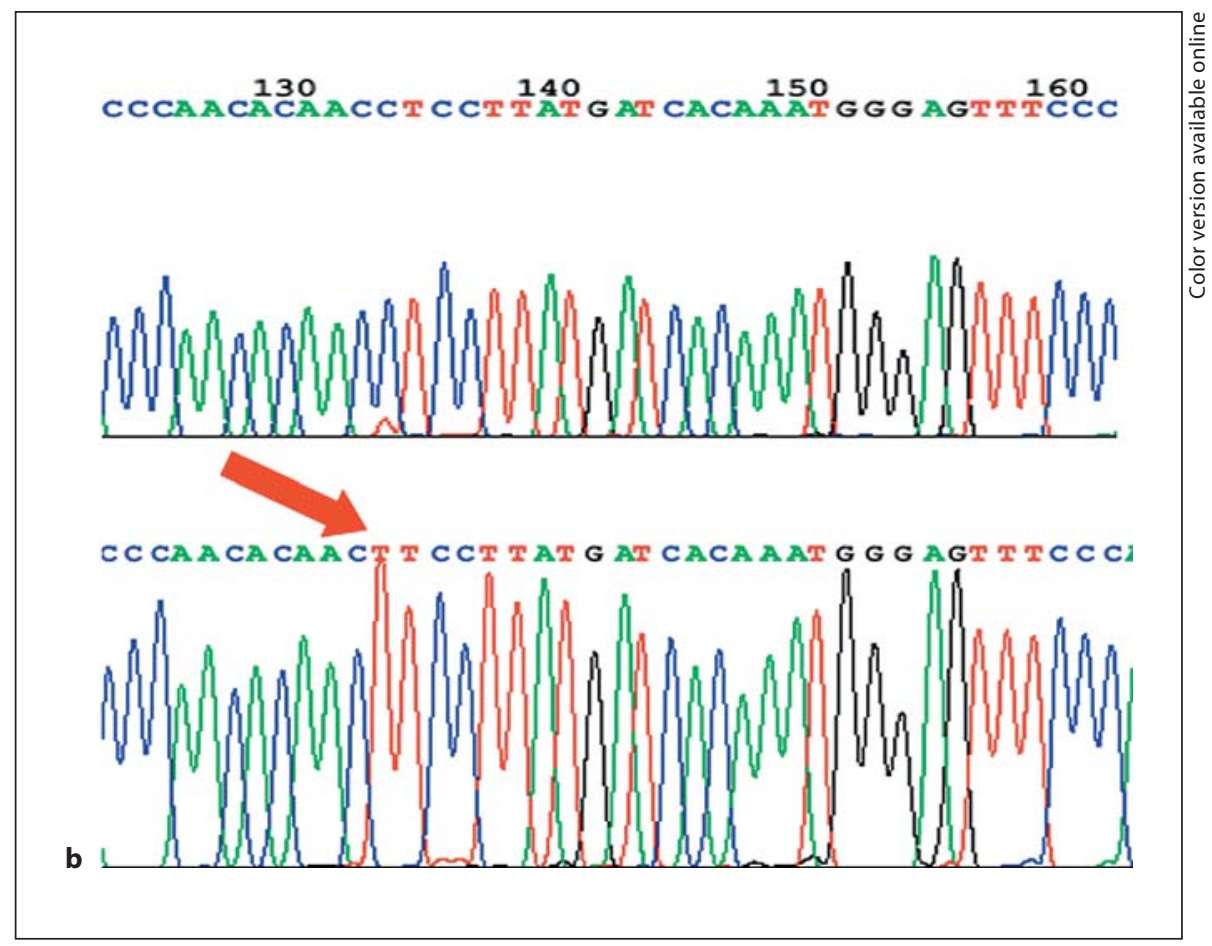

Table 1. Tumor evolution according to the RECIST criteria

\begin{tabular}{lll}
\hline Target lesion & $\begin{array}{l}\text { Before therapy } \\
\mathrm{mm}\end{array}$ & $\begin{array}{l}\text { After therapy } \\
\mathrm{mm}\end{array}$ \\
\hline $\begin{array}{l}\text { Lung metastasis } \\
\text { Visible part of local recurrence }\end{array}$ & 18 & 12 \\
Local recurrence (CT scan) & 25 & 14 \\
Lymph node inguinal right & 54 & 48 \\
Lymph node inguinal left & 42 & $44^{1}$ \\
\end{tabular}

RECIST $=$ Response Evaluation Criteria in Solid Tumors.

${ }^{1}$ The radiologist considered both inguinal lymph nodes to be possibly enlarged as a reaction to therapy.

One of the reasons for these findings might be that melanoma is not one disease but heterogeneous. In recent years, certain subgroups of melanoma patients characterized by certain targets have been described that may predict susceptibility to targeted therapies. However, it is currently unclear if patients will clinically benefit from targeted therapies that are guided by the absence or presence of susceptibility parameters.

One subgroup comprises melanomas that harbor $B R A F$ mutations. In small numbers of patients, specific BRAF inhibitors (PLX4032 and RAF265) induced tumor regressions in up to $70 \%$ of patients with BRAF V600E mutated metastatic melanomas [2, 3]. Further studies are ongoing to prove this treatment approach in a higher number of patients with $B R A F$ V600E mutated melanomas.

Melanomas with aberrations of the KIT gene might represent another subgroup which benefit from a therapy targeting the gene product c-KIT. Expression of c-KIT can be demonstrated in most mela- 

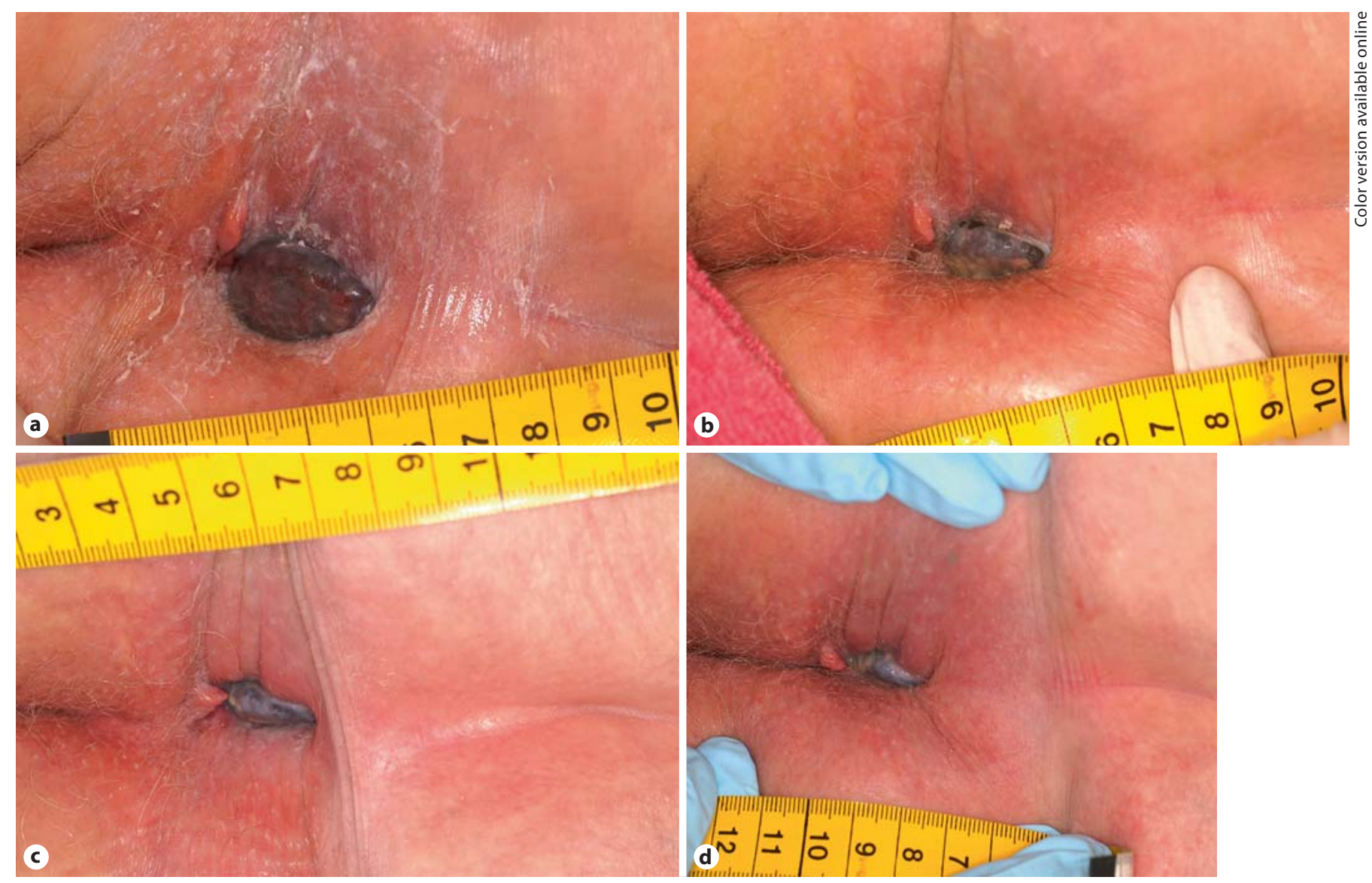

Fig. 2. Visible part of the tumor mass at the anus before treatment (a), decreasing after 7 days (b), 14 days (c) and 28 days (d) of imatinib therapy.

nomas by immunohistochemistry. However, studies of c-KIT blockers such as imatinib in unselected melanoma patients have been unsuccessful $[4,5]$. Recently, an increased frequency of KIT aberrations was described in mucosal melanomas and acral melanomas but not in melanomas of areas from intermittent sun exposure [6, 7]. These KIT aberrations comprise mutations or copy number increase of the KIT gene. KIT mutations occur in melanomas with no or little UV exposure (mucosal melanomas and acral melanomas) in up to $20 \%$, in cutaneous melanomas in $2.6 \%$ [8] or $2 \%$ of patients [9]. KIT gene amplifications in the absence of a KIT mutation occur in $18 \%$ of mucosal melanomas and $25 \%$ of acral melanomas but not in melanomas from sites of intermittent sun exposure [6]. In contrast, c-KIT protein expression can be detected in the majority of mucosal melanomas (up to $91 \%$ [7]), but also in a high percentage of cutaneous melanomas, i.e. up to $84 \%$ [10]. If KIT mutation or amplification rather than c-KIT expression is relevant for susceptibility to targeted therapies based on c-KIT blockade [1114], this might be the reason why phase II trials with the c-KIT blocker imatinib in unselected patients with metastatic cutaneous melanoma have been disappointing $[4,5]$.

Our case presented here and a growing number of case reports and interim data from ongoing phase II studies provide promising results that patients with KITmutated metastatic melanomas are amenable to single-agent therapy with one of the c-KIT inhibitors imatinib [13, 14], dasatinib [15, 16], sunitinib [17] or sorafenib [18]. In addition to this case, to our knowledge 13 further cases have been reported thus far who suffered from KIT-mutated metastatic melanoma and were success-

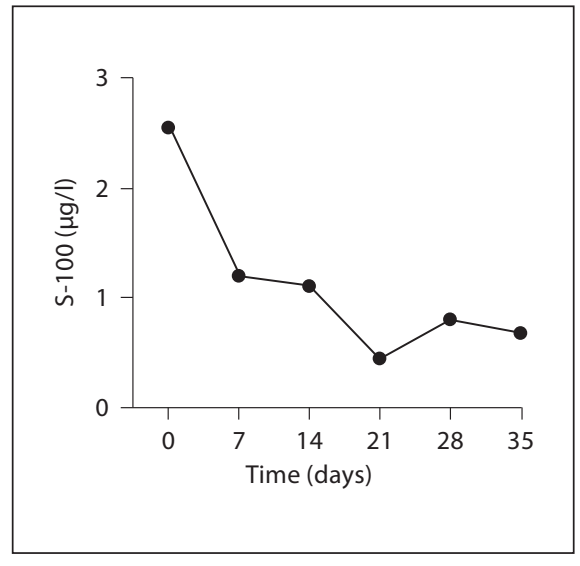

Fig. 3. The serum tumor marker S-100 fell during the treatment with imatinib from $2.56 \mu \mathrm{g} / \mathrm{l}$ before therapy (day 0) to 0.68 $\mu \mathrm{g} / \mathrm{l}$ after 35 days (normal $<0.2 \mu \mathrm{g} / \mathrm{l}$ ). 

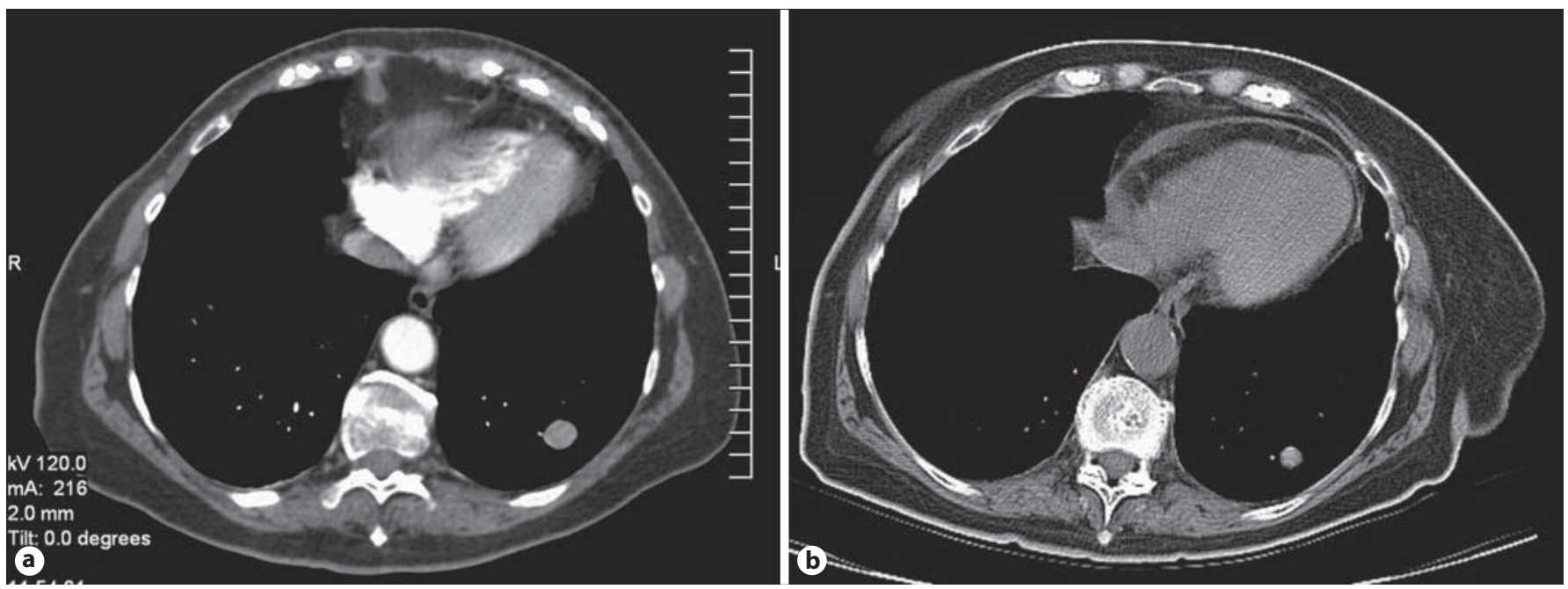

Fig. 4. Pulmonary metastases of anal mucosal melanoma at diagnosis of metastatic disease with a maximal diameter of $18 \mathrm{~mm}(\mathbf{a})$ and 12 weeks later with smaller diameter (maximum $12 \mathrm{~mm}$; b).

Table 2. Treatment of patients with KIT-mutated metastatic melanomas with tyrosine kinase inhibitors

\begin{tabular}{|c|c|c|c|c|c|c|}
\hline Type of melanoma & Patients & KIT mutation & $\begin{array}{l}\text { Therapeutic } \\
\text { agent }\end{array}$ & $\begin{array}{l}\text { Dose } \\
\text { mg/day }\end{array}$ & Response to therapy & References \\
\hline Mucosal melanoma & 1 & K642E, exon 13 & imatinib & $400-600$ & complete response & 14 \\
\hline Mucosal melanoma & 1 & 7-codon duplication, exon 11 & imatinib & 400 & major response & 13 \\
\hline $\begin{array}{l}\text { Acral and mucosal } \\
\text { melanoma }\end{array}$ & 5 & $\begin{array}{l}\text { exon } 11 \text { mutation ( } 3 \text { patients), exon } 11 \\
\text { amplification ( } 1 \text { patient), exon } 13 \text { mutation } \\
\text { ( } 1 \text { patient) }\end{array}$ & imatinib & $300-800$ & $\begin{array}{l}3 \text { patients partial response, } \\
2 \text { patients stable disease }\end{array}$ & 12 \\
\hline Mucosal melanoma & 1 & V560A, exon 11 & sorafenib & 800 & $\begin{array}{l}\text { complete response } \\
\text { (5 months) }\end{array}$ & 18 \\
\hline Mucosal melanoma & 2 & L576P, exon 11 & dasatinib & 140 & $\begin{array}{l}\text { both patients partial response } \\
(>50 \%)\end{array}$ & 16 \\
\hline Advanced melanoma & 2 & $\begin{array}{l}\text { (1) exon } 13 \\
\text { (2) deletion exon } 11\end{array}$ & dasatinib & $140-200$ & $\begin{array}{l}\text { (1) partial response } \\
\text { (2) no response }\end{array}$ & 15 \\
\hline Mucosal melanoma & 1 & V559A, exon 11 & sunitinib & 37.5 & partial response $(70 \%)$ & 17 \\
\hline Mucosal melanoma & 1 & L576P, exon 11 & imatinib & 400 & stable disease & this report \\
\hline
\end{tabular}

fully treated with kinase inhibitors targeting c-KIT (table 2). Twelve patients suffered similarly to our patient from metastatic melanoma with KIT mutations in exon 11 or exon 13 affecting the juxtamembranous region of the c-KIT protein, presumably resulting in an activation of cKIT (table 2). One patient showed only a KIT amplification (table 2). Only $1 / 13$ patients with KIT mutations had progressive disease during c-KIT-inhibiting therapy.
The patient with KIT amplification had a stable disease. Given the fatal outcome of metastatic melanoma without therapy, this strongly suggests a prognostic and therapeutic relevance of KIT mutations in melanoma, whereas the evidence for patients with KIT amplification without mutation is less clear.

It is interesting to note that all 5 patients described in detail in the literature and our patient responded rapidly to ther- apy with c-KIT inhibitors [13, 14, 16, 18]. Within the first 4 weeks of therapy, tumor masses and serum tumor markers decreased significantly in all patients. However, in our patient the tumor did not resolve completely. Lutzky et al. [14] reported a dose-dependent response to imatinib therapy in their patient, which raises the question if the imatinib dose of $400 \mathrm{mg}$ p.o. daily, given to our patient due to the side effects of therapy, was too low. Future 
studies are necessary to determine effective treatment parameters.

In summary, current data strongly indicate that melanomas with activating KIT mutations and possibly also with KIT gene amplifications respond to therapy with ty- rosine kinase inhibitors blocking c-KIT. Thus, subgroups of patients with metastatic melanoma prone to KIT mutations, such as primary mucosal and acrolentiginous melanomas, should be analyzed for their KIT status. In case of an activating muta- tion or gene amplification, a therapeutic attempt with a c-KIT blocker is reasonable. Clinical studies in such patients are warranted to better define the subgroup responsive to targeted therapy with c-KIT inhibitors.

\section{References}

1 Hauschild A, Agarwala SS, Trefzer U, Hogg D, Robert C, Hersey P, Eggermont A, Grabbe S, Gonzalez R, Gille J, Peschel C, Schadendorf D, Garbe C, O’Day S, Daud A, White JM, Xia C, Patel K, Kirkwood JM, Keilholz U: Results of a phase III, randomized, placebocontrolled study of sorafenib in combination with carboplatin and paclitaxel as secondline treatment in patients with unresectable stage III or stage IV melanoma. J Clin Oncol 2009;27:2823-2830.

2 Flaherty K, Puzanov I, Sosman K, Kim K, Ribas A, McArthur G, Lee RJ, Grippo JF, Nolop K, Chapman B: Phase I study of PLX4032: proof of concept for V600E BRAF mutation as therapeutic target in human cancer. J Clin Oncol 2009;27(suppl):abstract 9000.

3 Hersey P, Bastholt L, Chiarion-Sileni V, Cinat G, Dummer R, Eggermont AM, Espinosa E, Hauschild A, Quirt I, Robert C, Schadendorf D: Small molecules and targeted therapies in distant metastatic disease. Ann Oncol 2009;20(suppl 6):vi35-vi40.

-4 Kim KB, Eton O, Davis DW, Frazier ML, McConkey DJ, Diwan AH, Papadopoulos NE, Bedikian AY, Camacho LH, Ross MI, Cormier JN, Gershenwald JE, Lee JE, Mansfield PF, Billings LA, Ng CS, Charnsangavej C, Bar-Eli M, Johnson MM, Murgo AJ, Prieto VG: Phase II trial of imatinib mesylate in patients with metastatic melanoma. Br J Cancer 2008;99:734-740.

-5 Ugurel S, Hildenbrand R, Zimpfer A, La Rosee P, Paschka P, Sucker A, Keikavoussi P, Becker JC, Rittgen W, Hochhaus A, Schadendorf $\mathrm{D}$ : Lack of clinical efficacy of imatinib in metastatic melanoma. Br J Cancer 2005; 92:1398-1405.
6 Curtin JA, Busam K, Pinkel D, Bastian BC: Somatic activation of KIT in distinct subtypes of melanoma. J Clin Oncol 2006;24: 4340-4346.

7 Satzger I, Schaefer T, Kuettler U, Broecker V, Voelker B, Ostertag H, Kapp A, Gutzmer R: Analysis of c-KIT expression and KIT gene mutation in human mucosal melanomas. $\mathrm{Br}$ J Cancer 2008;99:2065-2069.

8 Went PT, Dirnhofer S, Bundi M, Mirlacher M, Schraml P, Mangialaio S, Dimitrijevic S, Kononen J, Lugli A, Simon R, Sauter G: Prevalence of KIT expression in human tumors. J Clin Oncol 2004;22:4514-4522.

$\checkmark 9$ Willmore-Payne C, Holden JA, Tripp S, Layfield LJ: Human malignant melanoma: detection of BRAF - and c-kit-activating mutations by high-resolution amplicon melting analysis. Hum Pathol 2005;36:486-493.

10 Giehl KA, Nagele U, Volkenandt M, Berking $\mathrm{C}$ : Protein expression of melanocyte growth factors (bFGF, SCF) and their receptors (FGFR-1, c-kit) in nevi and melanoma. J Cutan Pathol 2007;34:7-14.

11 Alexis JB, Martinez AE, Lutzky J: An immunohistochemical evaluation of c-kit (CD 117) expression in malignant melanoma, and results of imatinib mesylate (Gleevec) therapy in three patients. Melanoma Res 2005; 15 : 283-285.

12 Carvajal RD, Chapman B, WolchokJD, Cane L, Teichter JB, Lutzky J, Pavlick AC, Bastian B, Antonescu GK, Schwartz GK: A phase II study of imatinib mesylate (IM) for patients with advanced melanoma harboring somatic alterations of KIT. J Clin Oncol 2009;27 (suppl):abstract 9001.
13 Hodi FS, Friedlander P, Corless CL, Heinrich MC, Mac RS, Kruse A, Jagannathan J, Van den Abbeele AD, Velazquez EF, Demetri GD, Fisher DE: Major response to imatinib mesylate in KIT-mutated melanoma. J Clin Oncol 2008;26:2046-2051.

14 Lutzky J, Bauer J, Bastian BC: Dose-dependent, complete response to imatinib of a metastatic mucosal melanoma with a K642E KIT mutation. Pigment Cell Melanoma Res 2008; 21:492-493.

15 Kluger HM, Dudek A, McCann C, Rink L, Ritacco J, Adrada C, Phouyaphone N, Southard N, Sznol M: A phase II trial of dasatinib in advanced melanoma. J Clin Oncol 2009; 27(suppl):abstract 9010.

16 Woodman SE, Trent JC, Stemke-Hale K, Lazar AJ, Pricl S, Pavan GM, Fermeglia M, Gopal YN, Yang D, Podoloff DA, Ivan D, Kim KB, Papadopoulos N, Hwu P, Mills GB, Davies MA: Activity of dasatinib against L576P KIT mutant melanoma: molecular, cellular, and clinical correlates. Mol Cancer Ther 2009;8:2079-2085.

17 Zhu Y, Si L, Kong Y, Chi Z, Yuan X, Cui C, Sheng X, Guo J, Shen L: Response to sunitinib in Chinese KIT-mutated metastatic mucosal melanoma. J Clin Oncol 2009;27 (suppl):abstract e20017.

18 Quintas-Cardama A, Lazar AJ, Woodman SE, Kim K, Ross M, Hwu P: Complete response of stage IV anal mucosal melanoma expressing KIT Val560Asp to the multikinase inhibitor sorafenib. Nat Clin Pract Oncol 2008;5:737-740. 